\title{
Editorial: Special Issue - 'Roma Integration in the UK'
}

\author{
Ryan Powell* \\ CRESR, Sheffield Hallam University
}

\begin{abstract}
Anti-Roma sentiment, or "Romaphobia", has been on the increase across Europe in recent years alongside a growing anti-immigration discourse. So much so that the Roma 'are now seen as a "European problem" rather than a "European minority"' (Van Baar, 2011). Though far from a new phenomenon (see Lucassen et al., 1998; Mayall, 2004; Matras, 2014), repressive and controlling policies of dispersal and/or containment have emerged alongside the increased migration of Roma from Central and Eastern Europe to Western Europe (Vincze and Rat, 2013). At the same time the Roma have been the target of right-wing groups and political parties across Europe seeking to realise 'old nationalist ambitions' (Fox and Vermeersch, 2010). Such developments are not confined to Central and Eastern Europe however, as the illegal expulsion of Roma from France in 2010 and the well-documented treatment of the Roma in Italy illustrate (O'Nions, 2011; Picker, 2010).
\end{abstract}

Europe's Roma are often associated, through public and media discourse, with negative stereotypes which draw upon notions of (for example): an alien and nomadic culture; criminality; anti-social behaviour; benefit dependency; a lack of work ethic; and promiscuity. The persistence of old stereotypes was illustrated starkly last year by two widely reported, though completely groundless, stories of Roma stealing babies in Greece and Ireland. Such mythical perceptions still inform attitudes towards the Roma and contribute to their stigmatisation, marginalisation and segregation from the "mainstream". This is despite a concerted effort at the EU level to begin to address the centuries old persecution and hostility towards the continent's Roma and facilitate their integration within wider societies. Furthermore, in a similar vein to Gypsy-Traveller groups in the UK, the largely oral history of the Roma can also make it difficult to counter negative stereotypes as well as appreciate the rich diversity within the community (see Okely, 1983; Matras, 2014).

More recently, these anti-Roma sentiments have reached new heights within the UK with high profile cases of the Roma "problem", as it is increasingly constructed by politicians and the media, in Northern Ireland in 2008 (Clark and Rice, 2012) and more recently in Glasgow and Sheffield late in 2013. The latter case involved an unhelpful and inflammatory intervention from Sheffield MP David Blunkett (Pidd, 2013), which served as a further reminder (if one was ever needed) of the readiness of prominent public figures to resort to the same erroneous characterisations as that associated with the tabloid press. This growing hysteria crystallised around the opening of the UK's borders to the free movement of Bulgarians and Romanians in January 2014; the media and public response to which could certainly be perceived as a "moral panic" though one which needs to be situated within a much longer term process of Roma "problematization" (Van Baar, 2011; Matras, 2014). 
This Special Issue of PPP is a direct response to these worrying developments. It brings together leading academics in the field in order to address the changing context for Roma populations and the relationship between EU / national citizenship, integration / segregation, stigmatisation, marginalisation and media representations. The five papers drawn together here explore these issues from a multi-disciplinary perspective focusing on demographics, the legal framework, the role of the media and neighbourhood relations and perceptions.

Firstly, Helen O'Nions sets the scene at the European level through a discussion of the spread of Roma "problematization" and "securitization discourses" focusing on the relationship between "old" and "new" Europe and processes of EU enlargement in the context of the increasing attention to Roma issues. O'Nions explores the contradictions and tensions in the EU citizenship project from a socio-legal perspective and points to the failures of such a project 'when Europe's largest minority find themselves excluded from full membership'.

Philip Brown, Philip Martin and Lisa Scullion then draw upon their recent research estimating the size of the recently arrived Roma population in the UK. They critically reflect on whether conventional methodologies are suitable in application to 'a transnational and highly mobile ethnic group' and examine the strengths and weaknesses of a geo-demographic approach. Their paper also looks at the reaction to their research study in the context of a highly politicised arena and increasing international attention on Europe's Roma.

In the third paper Colin Clark provides a "micro-analysis" of the recent Roma situation in Govanhill in Glasgow and situates this within wider European debates around Roma migration, viewing Roma issues as common across Europe, east and west. Clark explores the issues in Glasgow alongside the responses and draws on insightful empirical data from an ongoing ethnographic study in the area. Clark argues that while Roma integration is challenging it is by no means impossible, but certainly dependent on the presence of a bottom-up Roma voice shaping service provision.

Jo Richardson then examines the reporting and political comment on the size and behaviour of the Roma population in the Page Hall area of Sheffield. Using an innovative application of the work of Foucault, Laclau and Mouffe, and concepts such as Galtung and Ruge's 'news values', Richardson places the discourse on Page Hall in the context of the wider Gypsy debate. Her insightful analysis attempts to counterbalance the hysteria characteristic of mainstream media accounts.

Finally, Judith Okely presents a unique anthropological perspective, drawing on her wealth of research experience within the community, through an examination of outsider (mis)representations of Gypsies, Travellers and Roma. Okely argues that illinformed pre-judgement dominates such coverage, and that centuries old stereotypes are recycled unchallenged. Okely reflects on her extensive fieldwork and insider ethnographic knowledge in unravelling and problematizing 'alarmist or melodramatic' representations.

Collectively, the papers in this Special Issue are intended to provide a rapid response to the increasingly prevalent processes of Roma stigmatisation and marginalisation. They seek to improve understanding of the issues involved and hopefully begin to bring some objectivity to a debate invariably characterised by stereotype, misunderstanding and misrepresentation.

* Correspondence Address: Ryan Powell, Centre for Regional Economic and Social Research, Sheffield Hallam University, Unit 10, Science Park, Howard Street, Sheffield, S1 1WB. Email: r.s.powell@shu.ac.uk 


\section{References}

van Baar, H. (2011) Europe's Romaphobia: problematization, securitization, nomadization. Environment and Planning D: Society and Space, 29, 203-212.

Clark, C. and Rice, G. (2012) Spaces of hate, places of hope: the Romanian Roma in Belfast, In: M. Stewart (Ed.) The Gypsy 'Menace': Populism and the New AntiGypsy Politics. London: Hurst and Company.

Fox, J. and Vermeersch, P. (2010) Backdoor nationalism. European Journal of Sociology, 50, 2, 325-357.

Lucassen, L., Willems, W. and Cottaar, A. (1998) Gypsies and Other Itinerant Groups: A Socio-Historical Approach. New York: Palgrave.

Mayall, D. (2004) Gypsy Identities 1500-2000: From Egipcyans and Moon-men to the Ethnic Romany. London: Routledge.

Matras, Y. (2014) I Met Lucky People: The Story of the Romani Gypsies. London: Allen Lane.

Okely, J. (1983) The Traveller-Gypsies. Cambridge: CUP.

O'Nions, H. (2011) Roma expulsions and discrimination: The elephant in Brussels. European Journal of Migration and the Law, 13, 4, 361-388.

Picker, G. (2010) Nomads' land? Political cultures and nationalist stances vis-à-vis Roma in Italy, In: Stewart, M. and Rovid, M. (Eds) Multi-disciplinary perspectives on Romany Studies, pp. 211-227. Budapest: Central European University Press.

Pidd, H. (2013) 'Slovakian Roma in Sheffield: "This is a boiling pot ready to explode"', The Guardian, 15 November 2013.

Vincze, E. and Rat, C. (2013) Foreword for the Special Issue on 'Spatialization and racialization of social exclusion: The social and cultural formation of "Gypsy Ghettos" in Romania in a European context. Sociologica, 58, 2, 5-22. 